The Geneva Papers on Risk and Insurance, 17 (No. 63, April 1992), 178-199

\title{
Insurance and the European Community
}

\author{
by William E. Pool
}

\section{Introduction}

The influence exercised by the European Community (EC), ${ }^{1}$ not only on its citizens and their business activities, but also on other European countries and the world at large, is constantly growing.

Linked to this is a perpetual evolution of its membership, its links with non-member countries, the definition of its goals, the role of its institutions and its entire legal framework. The part it plays in shaping markets for insurance, and indeed financial services in general, is caught up in this. To understand it, we need more than a description of the present state of affairs, since this is only a stage in a continuing progression. We must also look to past origins and future objectives. This is all the more necessary in that not all categories of insurance, and not all Member States, have reached the same point on the road.

The present article seeks to place Community measures affecting insurance within a historical context and to relate them to the wider evolution of the Community. It also explains why the "1992 single market", about which we hear so much, will come late for insurance.

Annex I briefly outlines the insurance directives already in force, together with those that are progressing towards that point. The full titles and references of the directives mentioned in the main text will be found there.

1 The European Community is based on treaties. At the outset, in the 1950 s, there were three treaties, setting up:

- The European Coal and Steel Community

- The European Atomic Energy Community

- The European Economic Community (EEC Treaty - Treaty of Ronie - 1957).

Strictly, therefore. one should speak of the European Communities, but the three were largely integrated by the Merger Treaty of 1967. The founding treaties have been amended by the Single European Act of 1986 (entry into force: 1 July 1987) and now by the Treaty of Maastricht.

The original signatories of the founding treaties were Belgium, Germany. France, Italy, Luxembourg and the Netherlands. Denmark, Ireland and the United Kingdom acceded by virtue of a treaty of 1972. Greece by a treaty of 1979 and Spain and Portugal by a treaty of 1985. 


\section{The starting point}

The EEC Treaty looked to the creation of a common market for services as well as goods, and the EC Commission had to take the initiative in bringing this about. All the same, in the early days attention was concentrated on creating the customs union and moving towards a common market in goods, so that work on services got off to a slow start.

Insurance was heavily regulated in all six original Member States, but by different means and to some extent with different objectives. The Commission, perceiving this regulation to be the main factor walling off the separate national markets, saw its main task to be the coordination of insurance supervision throughout the Community.

The separation of national markets was least pronounced in reinsurance, which was seen therefore as an easy target, to be tackled first: the few obstacles were removed by a Directive adopted as early as 1964 . At the other extreme, divisions appeared most marked in life insurance, where national ideas on consumer protection, the promotion of the economy, currency protection, social objectives and taxation were combined with different attitudes to composite insurers and even divergent conceptions of the scope of life insurance itself. For this reason the first directive in life insurance was not adopted until 1979, and work on life insurance has been left until last at each subsequent stage.

\section{The goal}

The nature of the envisaged common market in financial services, including insurance, was brought into sharper focus by the Commission's White Paper of $1985,{ }^{2}$ which launched the 1992 programme subsequently enshrined in the Single European Act. ${ }^{3}$ Later pronouncements by Commissioners have further refined the concept. The characteristics of the single internal market, as it is now customarily called, may be summarized as follows:

- producers of financial services must be able to set up business anywhere within the single market, and to sell the same products throughout it from any base; they must moreover be able to invest their funds anywhere within the Community; this must take place in conditions of fair competition (the "level playing field");

- buyers must be able to buy where they like and to have access to any product on sale anywhere within the market;

- intermediaries must be able to operate in single-market conditions;

- good and comparable information about products, and above all about the financial standing of producers (and, where appropriate, intermediaries), must be available throughout the market;

- differences in taxation, contract law, marketing regulations and so on must not be allowed to distort the market; in particular, consumer protection measures - the importance of which is fully acknowledged - must be compatible with the operation of the single market.

2 "Completing the Internal Market" - White Paper from the Commission to the European Council - June 1985. Within Part II, "The Removal of Technical Barriers", Section IV deals with the common market for services, with a part devoted specifically to financial services.

${ }^{3}$ The Single European Act states: "The Community shall adopt measures with the aim of progressively establishing the internal markct over a period expiring on 31 December 1992". For insurance this obviously needs to be taken with a pinch of salt. 
The White Paper outlines a regulatory framework which has thenceforth formed part of the Commission's objectives. The central concept is "home country control with mutual recognition of standards". As now formulated, this consists of three elements:

- all prudential supervision is to be in the hands of the home Member State (where the financial institution has its headquarters) ("home country control");

- each Member State must respect the prudential supervision carried out by the others ("mutual recognition");

- underpinning this, there will be sufficient harmonization of minimum or essential standards for prudential supervision and for the protection of the public.

The result is intended to be a regulatory system which will:

- create a highly competitive environment;

- but nevertheless maintain public confidence in financial institutions;

- remove those differences in national regulatory structures which separate markets.

This regulatory system will certainly make it easier for producers to operate throughout the Community by means of branches or cross-frontier transactions, as may suit them best. However, it is not enough in itself to produce a single market. The stress is on financial regulation and the proper running of providers of financial services.

It is not so clear what will be done to ensure that the same products may be put on the market throughout the Community. If product control, in the guise of consumer protection, is left in the hands of the buyer's country without Community coordination, the goal is not reached. This is an area in which uncertainty still reigns.

The thinking of the EC policymakers has now moved forward to contemplation of a single Community-wide currency. The relevance of this to the market in financial services is obvious, but at the moment we can only wait and see.

\section{Means}

The EEC Treaty provides two principal means for attaining the single internal market:

- ihe right of establishment; and

- the right of freedom of services.

The right of establishment, in insurance, means in particular the right of an insurer having its head office in one Member State to open a branch or agency in another and to be treated thcre on equal terms.

Freedom of services has been thought of, at least by the Commission, as the right for an insurer established in one Member State (whether through its head office or a branch) to cover across frontiers a risk or policyholder in another State (even if the insurer also has an establishment there).

Secondary legislation is needed to enable these rights to be used in practice. In insurance, the legal instrument almost invariably adopted for this purposc is the directive. To quote Article 189 of the EEC Treaty:

"A directive shall be binding, as to the result to be achieved, upon each Member State to which it is addressed, but shall leave to the national authorities the choice of form and methods." 
The Commission originally expected to reach the goal through two generations of directives concerned with regulation. Directives of the first generation would deal with establishment and those of the second with freedom of services. Within each set, there would be first a non-life directive and then, somewhat later, a life directive.

In the event, three generations of directives have been needed, for reasons explained later. At present, the third-generation directives are only at the proposal stage (one being now near adoption), and although both second-generation directives have been adopted, only one is yet in force.

In addition, separate directives are required for important ancillary purposes, an example being the directive on the published accounts of insurance undertakings. Mention should also be made of the series of directives concerned with motor insurance, which benefit the movement of traffic across national borders and improve the protection of accident victims.

Initially, insurance directives had to be adopted by the unanimous vote of all Member States. Progress under such a system is inherently difficult, and the problems became unmanageable as the number of Member States increased.

The Single European Act greatly improved the decision-making process. For insurance regulatory measures, unanimity is no longer needed. Instead, there is qualified majority voting, details of which are given in Annex 11. This method has fully proved its worth in the field of insurance.

However, unanimity is still needed for taxation and most social security measures.

Under the Single European Act, the standard procedure for insurance directives is as follows:

(1) The Commission makes a proposal (usually after extensive studies and consultations). It may amend it at any time.

(2) The proposal is examined by the Economic and Social Committee and, more importantly, by the European Parliament in a first reading, without time limit. Both bodies deliver Opinions (which may persuade the Commission to amend its proposal).

(3) The Council of Ministers examines the proposal (in practice, underlings do most of the work, frequently starting before the Opinions are received). It arrives at a "common position", usually by qualified majority vote. The text may by now differ considerably from the original proposal, and the Council will have to vote unanimously if the Commission does not accept the changes.

(4) The "common position" goes to Parliament for a second reading, with a three-month time limit. Parliament can only cause an upset at this stage if an absolute majority of members vote to amend or reject the "common position" text.

(5) Once Parliament has approved it, the Council adopts the text. It is then notified to the Member States.

(6) The Member States have a period (for insurance measures this is in practice never less than two years) in which to apply amended national legislation to comply with the directive. Extended deadlines, well beyond the nominal entry into force, may be granted for the application of certain provisions by some or all of the Member States.

(7) The Commission monitors application of the directive. Disputes may have to be settled by the European Court of Justice. 


\section{Directives of the first generation}

The practical exercise of the right of establishment was made possible by the two First Insurance Coordination Directives.

The First Non-Life Directive, of 24 July 1973, is the fundamental text on which most subsequent work has been constructed. Its main provisions cover the following:

- the legal form of insurance undertakings;

- the restriction of their activities to insurance and operations directly arising therefrom;

- the requirement that all classes of insurance must be subject to State supervision;

- the assignment of responsibility for supervision of technical provisions and of the assets covering them to the State where each establishment (head office, branch or agency) of the insurer is situated (the provisions have to be "sufficient", but there is no harmonization);

- the attribution to the head office State of sole responsibility for ensuring maintenance of the prescribed solvency margin (over and above the technical provisions) and guarantee fund (their level being determined by the Directive);

- procedures for creating new insurance undertakings and for setting up branches in other Member States - if the insurer complies with the conditions, authorization cannot be refused (in particular, economic need is not a relevant criterion; an insurer seeking to set up a branch must produce a certificate of solvency issued by the head office State, which the other State must accept);

- various measures, culminating in the withdrawal of authorization, to be taken if things go wrong;

- close cooperation between national supervisory authorities.

The First Life Directive, of 5 March 1979, was based upon the First Non-Life Directive, and achieves the same purposes. However, it is longer and more complicated, for three main reasons:

- the solvency margin rules take account of the varying mix of risk-covering and investment in different types of life insurance;

- what life companies were expected or permitted to do differed from one State to another - the Directive avoids harmonization of the concept of life insurance, but at the price of virtually allowing each Member State to decide for itself what life companies may do within its borders;

- the problem of composite undertakings (carrying on both life and non-life insurance) was tackled: no new composites or branches might be formed, but existing ones might continue.

It may be mentioned in passing that three later measures have been adopted to tie up certain loose ends left by the First Non-Life Directive. They concern respectively:

- assistance activities (especially tourist assistance);

- credit and suretyship insurance;

- legal expenses insurance.

The First Directives set up a multiple-authorization system. Each State where the insurer has an establishment, whether head office, branch or agency, authorizes the 
insurer and is responsible for the supervision of the technical reserves and much besides. The head office State has certain overall responsibilities, including the solvency margin.

This can be contrasted with the single-authorization concept (also referred to as the single licence or European passport idea), which is the ultimate goal.

Although the First Directives give better access to the national markets, they do not create a single market. A branch has to behave as part of the national, separately regulated, market in which it is set up.

\section{Court judgments of $\mathbf{1 9 8 6}$}

For the next stage, the Commission tried to rely upon a wide interpretation of the direct effects of the Treaty provisions concerning freedom of cross-frontier services, but most Member States vehemently resisted.

For a time there was deadlock. However, on 4 December 1986 the European Court gave relevant judgments in four cases, the main one being no. 205/84, Commission v. Federal Republic of Germany (covering life as well as non-life insurance).

The Court declared that the requirement upheld by many States that the insurer had to be established in their territory could not be maintained. However, it went on to say that national laws had not yet been brought sufficiently into line to guarantee policyholder protection in sensitive areas. Until this was done, the State where the policyholder was resident or the risk was situated might - for the sake of safeguarding the "general good" - impose onerous requirements on the insurer based in another State. These included an authorization in the host State, which might insist upon the application of its own rules in two areas:

- technical provisions, including the calculation of the provisions and the nature and localization of the assets covering them; and

- general and special policy conditions (which determine the nature of the insurance product).

However, the Court also indicated that there were circumstances (which it did not spell out) in which protection of the policyholder or insured person was not the prime consideration. In such cases, the authorization and attendant controls in the destination State were not justified.

The Court did not state what it meant by the "general good" ("intérêt général", "Allgemeininteresse"), but gave the impression that - for the purposes of this case - it could be broadly equated with reasonable consumer protection.

This judgment meant that establishing the single market in insurance was not going to be as simple as had been hoped. More coordination of laws than envisaged in the Commission's 1985 White Paper would be needed to usher in home country control.

\section{Directives of the second generation}

Because of the Court judgment, the Commission decided to proceed to a full common market by two further generations of directives - the second and the third - instead of trying to get there in one bound (as had been envisaged in the timetable annexed to the White Paper). We thus have the Second Non-Life and Second Life Directives, and now proposals for the Third Non-Life and Third Life Directives. The hope was that the directives of the second generation, going part of the way to the ultimate goal, could be pushed through quickly. 
The two Second Directives deal with cross-frontier insurance and, in line with the judgments, separate out cases where there is no need for consumer protection. For them, a scheme of virtually full freedom from risk-country control is set up. The remaining cases, where national protection is justified, come under an authorization regime in the State where the risk is situated.

The Second Non-Life Directive accordingly provides that for the so-called large risks (in general, major industrial and commercial policyholders) ${ }^{4}$ financial regulation is carried out by the State where the insurer is established. For mass risks (everything else), on the other hand, the State where the risk is situated may insist on authorization and apply such controls that cross-frontier business will rarely be attractive.

The Second Non-Life Directive was adopted in June 1988, by qualified majority voting, and came into force in July 1990 . It is a major breakthrough, because it establishes a fairly complete single market in the area of greatest commercial need, where international brokers and professional risk managers are equipped to make good use of freedom. A policyholder with risks in several Member States is enabled to insure them under a single contract, without the need for complicated and expensive fronting operations, and can, if desired, set up a direct insurance captive to cover them.

A different approach is taken in the Second Life Directive (adopted in November 1990, but not entering into force until May 1993). The thesis here is that although the life policyholder may expect the protection of his own State when insurance is actively sold to him, he voluntarily abandons it when, on his own unpressured initiative, he chooses to seek cover in another Member State.

For a policyholder who grasps the initiative, the single market will become as much of a reality as is possible without a single currency. The State where he is resident may not stop him from entering into any life contract - even if it is of a kind prohibited there - unless it is contrary to public policy (ordre public), which is generally considered to be a rather narrow concept under Community law.

For many States this means a big change. However, under freedom of capital movements (general, with a few exceptions, from summer 1990) they would in any case find it difficult to prevent their residents from buying life insurance in other Member States. Furthermore, under the so-called UCITS Directive, mutual funds, unit trusts and SICAVs have been able to market their products throughout the Community since October 1989. Savings-orientated life insurance would be at a disadvantage if nothing was done.

4 From 1 January 1993 "large risks" will be:

1) transport risks (without thresholds)

2) credit and surety risks (without thresholds, but related to the policyholder's commercial activity)

3) fire and general property damage, general civil liability and pecuniary loss, to the extent that the policyholder or a group of companies of which the policyholder is a member fulfils two out of the three following conditions:

a) 250 employees,

b) turnover of 12.8 million ECU

c) balance sheet total of 6.2 million ECU.

During a transitional period from July 1990 to end 1992, these thresholds are roughly doubled. A lengthy transition with progressive stages is provided for Spain, Portugal, Greece and Ireland; the last three do not catch up with the majority States until I January 1999. 
All the same, the Directive contains several indications of the cautious attitude of many States. For example, although the policyholder exercising his initiative in approaching an insurer in another country may in principle do so through an independent broker in his own country, Member States are allowed to delay application of this provision until 20 May 1996 - three years after the Directive comes into force, and more than three years after the much-trumpeted date of 31 December 1992 when the single market is supposed to come into being.

Moreover, Member States need not apply the provisions on the exercise of "own initiative" to group insurance related to employment until 31 December 1994. These provisions are probably the most important part of the Directive in commercial terms, since they concern occupational pensions and other employee benefits involving very large sums.

It comes as no surprise after this that the Directive will not apply fully to Greece and Portugal until 1 January 1999.

These remote deadlines, it will be noted, are in what is only a stopgap second-generation Directive, with the third generation still to come! However, the present pace of events is such that the forthcoming Third Life Directive will perhaps supersede the Second Life Directive before some of the latter's provisions have had time to come into force.

\section{Directives of the third generation}

The Second Directives, so far from introducing single authorization, actually extend the multiple-authorization system set up by the First Directives. Thus for example a non-life insurance company, having its headquarters in State A and a branch in State B, from which it covers mass risks in State $C$, requires an authorization in each of the three States $A, B$ and $\mathrm{C}$. To move beyond this, the third generation of directives is needed. The Commission has accordingly made proposals for Third Directives (non-life: 18 July 1990; life: 20 February 1991).

Much of their text is taken up with replacing the existing complicated allocation of responsibility for supervision with the new single-authorization arrangements, modelled on those of the already adopted Second Banking Directive.

Under the proposals, an insurance company having its head office in a Member State of the European Community will need to be authorized only in that State (known as the home State) to enable it to cover the entire Community market. It will be able to set up branches or to sell insurance across frontiers, or to use any combination of the two, without requiring further authorization from the other States concerned.

Home-State authorization will still be based on the scheme laid down in the First Directives, but it is proposed that supervision will be of a more "hands off" kind than the form of "material control" hitherto favoured in some Member States. In particular, the possibility for Member States to require the prior approval of policy conditions and premium rates would be abolished.

On the other hand, authorizing States must ensure that insurance undertakings are run by "technically qualified persons of good repute" and must be informed of the identity of shareholders and members holding a qualifying participation (normally 10\%). Authorization will be refused if the authorities "are not satisfied as to the suitability of the said shareholders or members". There will be ongoing monitoring and power to intervene. 
Sole responsibility for the financial supervision of the insurance undertaking is placed in the hands of the home State.

An insurer wishing to set up a branch in another Mcmber State has to supply certain information to the compctent authority of its home State (only), which, if satisfied, communicates it to the prospective host State.

For its part, the host State may "indicate the conditions under which, in the interest of the general good" the proposed activities must be carried on there. However, it cannot block the creation of the branch; and if the home State itself does not raise objections, the branch can be set up within a maximum of five months from the submission of the application.

The home State will be empowered to carry out on-the-spot financial checks on a branch in another Member State.

New streamlined procedures will apply when an insurer engages for the first time in cross-border services business in another State. They supersede the previous distinctions between large risks and mass risks (in non-life) and between own-initiative purchases by the policyholder and active marketing by the insurer (in life insurance).

Home country control of financial requirements is matched by greater Community coordination of them, thereby making possible the necessary mutual recognition of standards.

In particular, the proposals deal with the technical provisions and with the assets covering them.

In non-life insurance, the home State must ensure that the insurance company establishes technical provisions for its entire business in accordance with the detailed rules laid down in the Directive on the Annual Accounts and Consolidated Accounts of Insurance Undertakings (see below). The consequence will be a considerable degree of harmonization, although practices will still differ considerably over equalization reserves.

In life insurance, the Commission has drawn on a study carried out by the Consultative Group of the Associations of Actuaries of the Member States of the Community. This showed that certain widely accepted principles underpinned the superficially different methods adopted by national rules and practices. Following the Group's recommendation, the proposal requires explicit recognition of these principles, without attempting to achieve full detailed harmonization of methods. The result will presumably be that methods will continue to differ widely; but under the principle of mutual rccognition each State will have to accept as valid what is done under the auspices of another, however unfamiliar it may seem. The Commission evidently hopes to counteract objections through publicity requirements. Hence life insurers will be required to publish the bases and methods used in the calculation of the technical provisions, including provisions for bonuses.

The two proposals do not diverge greatly in their rulcs on the assets covering the provisions.

They set out a general principle for the investment of assets covering technical provisions, and more specific rules on the admissibility, diversification, localization and valuation of investments and on currency matching requirements.

Member States will be prohibited from requiring insurers to invest in particular categories of assets: thus there can be no compulsory minimum holdings of state bonds, for 
instance. Moreover, they may not require assets to be located in their national territory, but only within the boundaries of the Community as a whole.

Many of the proposed rules are decidedly liberal compared with what is at present admitted in many Member States. For example, a life insurance company may be permitted by its home State to invest all its technical provisions, including mathematical provisions, in quoted shares.

Surprisingly, there is no limit on the use of reinsurance to cover the gross technical provisions, and nothing specific is said about controlling the quality of reinsurance.

Member States may in all cases allow the prudent use of current values of investments for regulatory purposes, in life as well as non-life insurance.

Most of the proposed rules on investments are of a minimal nature: individual States may apply stricter provisions, but only to insurers whose head office is in their territory. Many insurers, fearing competition problems, would prefer this option to be abolished.

In a reversal of the line taken in the First Life Directive, the formation of new composite insurers, and composite branches, would be permitted. There would however still be strict segregation of the two parts of the business for the purposes of financial control.

Many of the proposed rules are controversial, and may be much modified before the Directives are adopted. All the same, because they will provide Community-wide coordination of technical provisions and the assets covering them, they will remove one of the two grounds which the Court held in 1986 to justify market-divisive intervention by host Member States.

The other area where the Court thought Member States were justified in imposing their own rules was that of controls on general and special policy conditions: those supervisory rules which determine what products may be marketed. If there is no coordination here, insurance which may be bought and sold in one Member State may be prohibited in another, and one of the Commission's stated objectives will remain unrealized.

The proposals for the Third Directives, although prohibiting States from requiring prior approval of policy conditions, disappointingly fail to tackle the main problem. They merely say:

"The Member State in which the risk is situated shall not prevent the policyholder from concluding a contract conforming with the rules of the home Member State, as long as it does not conflict with legal provisions protecting the general good in the Member State in which the risk is situated" (non-life proposal - the life text is slightly different - my italics).

This leaves things where they were after the 1986 judgment. In the absence of Community rules, Member States will decide independently, and differently, what constitutes the general good.

Any insurer considering that national restrictions are not justified on grounds of the general good will be able to bring a case to the European Court. The challenged State will have to satisfy the Court that its legal provisions do indeed protect the general good, are not disproportionate to the purpose, cannot be replaced by less restrictive measures and do not duplicate provisions to which the insurer is already subject in its home State. Probably a jurisprudence will emerge which will lead in the end to a de facto harmonization: but how long will it take? 
No doubt the "general good" test must be retained as a residual safeguard, since directives cannot cover every eventuality, and should not try to do so. However, it is surprising that nothing is done to restrict at the outset the number of cases that might go to the Court

In a speech of 18 March 1991, Sir Leon Brittan, Vice President of the Commission, said, in connection with life insurance:

"Member States will not, for instance, be able to plead the 'general good' to prevent their citizens from buying a unit-linked insurance contract, or a contract with nonguaranteed surrender values, or one without participation of profits, as some countries do at present."

The Commission's proposal could have laid down explicitly that Member States must permit the mentioned products to be sold in their territory. Instead, if any Member State disagrees with the view expressed by Sir Leon Brittan, the Court will have to decide.

Similar references to the "general good" are found in the Commission's proposals in all areas of financial services. However, different interpretations are particularly likely in life insurance because, as already noted, the First Life Directive allowed widely divergent national attitudes to carry on flourishing. In this field, more than most, one man's consumer protection is another man's protectionism.

The Commission appears to hope that these problems will gradually wither away. If it is wrong, a fourth generation of directives may yet be needed.

A large measure of consumer protection is already provided by the rules on the choice of the national law applicable to insurance contracts (such law governs the relations between the parties and can be largely distinguished from rules about what products may be sold). The extent of the choice granted is graduated according to the policyholder's circumstances. The aim is that smaller policyholders shall never find themselves in a situation where a national contract law is applied with which they have no apparent connection. It is always the policyholder's circumstances that count, and not those of the insurer.

On the other hand, the attempt launched more than ten years ago to standardize some major elements of contract law in non-life insurance has been abandoned for the foreseeable future.

In the proposal for a Third Life Directive the Commission makes two further valuable moves in favour of consumer protection. Firstly, policyholders must in all cases be given a cooling-off period, of between 14 and 30 days starting from the conclusion of the contract, during which they may resile from their commitment. Secondly, before the contract is concluded, and in some circumstances whilst it is running, policyholders must be given specified information intended to enable them to understand its nature. ${ }^{5}$

5 The information includes many uscful things, such as an "indication of surrender and paid-up values, and the extent to which they are guaranteed"; it also extends to "means of calculation and distribution of profit participation". where one wonders if it can be done in a practical way that will permit ordinary policyholders to compare information given by companies in different countries. 


\section{Taxation aspects}

Insurance premiums are not subject to value-added tax. Instead, there exists a profusion of premium taxes and parafiscal levies.

Community law intervenes only to apply the so-called territorial principle. Each Member State has the right to charge its own premium taxes on the insurance of risks situated in its territory, and to use its own means to collect the tax, regardless of whether the insurer covering the risk is situated in the same State or another one. There is thus no harmonization, but equality of treatment within each Member State between "services" and "establishment" business.

This scheme is already in force under the Second Non-Life Directive, but it is too early to say how effective it is. Where the policyholder and the insurer are in the same State, the tax is almost invariably collected from the insurer. Cross-frontier insurance operations present the challenge of finding means of collecting the tax without loss of revenue, but also without procedures so cumbersome that they make such insurance unattractive.

The rules under which many Member States permit the deduction of life insurance premiums for tax purposes present another problem. If the deduction is refused where the premium is paid to an insurer outside the taxing country, there is an apparent discrimination. However, in two judgments of 28 January 1992 the European Court has ruled that such rules may be maintained where there is no other way of maintaining the coherence of the national tax system.

\section{The Directive on the annual and consolidated accounts of insurance undertakings}

This long and complex Directive, recently adopted and not yet in force, adapts the provisions of the Fourth Directive on Company Accounts and the Seventh Directive on Consolidated Accounts to the needs of insurance. It concerns non-life and life direct insurance and reinsurance, extending to cover specialist reinsurance companies.

The Accounts Directive will enable information on the financial situation of insurance undertakings anywhere in the Community to be available in a standard comprehensive form to buyers of insurance and their advisers, wherever in the Community they may be, and will thus play an important role in the operation of the single market. ${ }^{6}$

\section{The proposed Directive on the compulsory winding up of insurance undertakings}

The purpose of the proposed Directive on the Compulsory Winding Up of Insurance Undertakings is to establish rules to apply when the withdrawal of authorization, especially in the event of insolvency, leads to a compulsory winding up.

Although the need for a directive of some kind in this area is widely recognized, there is no consensus among the Member States on the best way of setting about it. In consequence, no Council presidency has so far felt that the chances of success are sufficient for it to be worth while putting the proposal on the agenda for meetings of a Council working group.

${ }^{6}$ The Directive will, among other things, require insurers to disclose both the historical cost and the current value of their investments. 


\section{Application of competition rules}

The applicability of the Treaty's competition rules to the insurance sector was comprehensively confirmed by the judgment of 27 January 1987 of the European Court of Justice, in case 45/85 (Verband der Sachversicherer e. V. v. Commission of the European Communities). The Court dismissed an appeal against the Commission's decision finding that the Association of German Property Insurers had infringed the competition rules in recommending that commercial rates should be increascd by betwcen $10 \%$ and $30 \%$ in the industrial fire risks class.

This decision of the Court gave a ncw stimulus to the Commission's approach to competition in the insurance area.

In general terms, the Commission seeks to ensure that companics and Member States do not engage in market rigging or other protectionist activities which corrupt the process of competition. At the same time collaboration between firms which stimulates competition must be encouraged. The distinction between the two types of activity must bc made as clear as possible for all concerned.

To help achieve this, the Commission intends to put forward a group exemption regulation for the insurance sector. Such a regulation would codify the categories of agreement which qualify automatically for exemption without the need for prior notification, and lay down the conditions and obligations to which such exemption is subject.

The establishment of a group exemption requires a two-step procedure, which is now in course.

\section{Non-Community insurers}

The rapid moves towards completion of the internal market have increased the interest of operators in non-member countries in obtaining a foothold within it, and also given rise to fears that a "fortress Europe" would put them at a disadvantage. It is therefore pertinent to examine the situation in insurance.

A non-Community insurer can have access to the Community direct insurance market in one of the following ways, each of which has its distinct legal framework:

- covering a risk situated in the Community directly from a base situated outside;

- using a branch or agency established inside the Community; or

- using a subsidiary company established inside the Community.

The direct cover of a risk deemed to be situated within the Community is possible if the Member State concerned so permits; this will in particular often be the case for the cover of international trade and transport.

Apart from the Agreement with Switzerland, discussed below, no Community rulc obliges Member States to authorize non-Community insurers to set up branches in their territory. Any Member State that does permit this must, however, obcy Community rules designed to ensure that the insurer is not treatcd morc favourably than a Community insurer would be. The branch must, among other things, maintain its own solvency margin. Howcver, it does not benefit from Community rules on freedom of cross-frontier services, and may only cover risks in anothcr Member State if that State so permits. 
After exceptionally long negotiations, the Community has concluded an Agreement with Switzerland in the field of direct non-life insurance. Under the Agreement, Switzerland will apply rules similar to those contained in the First Non-Life Directive. Swiss non-life insurers will then be able to establish branches in the Member States of Community in conditions similar to those applying to Community insurers, who for their part will enjoy similar rights in Switzerland. The Agreement does not, however, extend to the cross-frontier provision of services, either within the Community or bctween the Community and Switzerland.

The use of a subsidiary company, established within the Community but owned by non-Community interests, is perhaps the most popular way for non-Community insurers to do business inside the Community. Recent moves by the Community to arm itself with powers linked to the concept of international reciprocity caused something of a scare at first, but the texts in fact adopted seem to have assuaged most of the anxieties.

The procedures incorporated into the Fourth Motor Insurance Directive (for the whole of non-life insurance) and the Second Life Directive (for the whole of life insurance) provide that the Commission shall:

- build up a complete picture of the group structure where an insurer within the Community is a subsidiary of non-Community interests;

- be informed of difficulties Community insurers experience in setting up or carrying on business in non-Community countries.

The mere absence of "effective market access comparable to that afforded by the Community" (mirror-image reciprocity) will not entitle the Community to do more than negotiate with the country concerned.

The Commission may initiate tougher action if it finds that there is effective discrimination against Community insurers. Effective discrimination will exist if:

- Community insurance undertakings do not enjoy national treatment in the country concerned, affording the same competitive opportunities as those enjoyed by national insurance undertakings; and

- the conditions necessary for effective market access are not met.

The tougher action would consist of restricting:

- the grant of insurance authorizations to new subsidiaries in the Community;

- permission to acquire a stake in an already authorized insurer sufficient to make it a subsidiary.

Such tougher action, once proposed by the Commission, would have to be approved by the Member States.

Although provisions similar to these exist elsewhere in the financial services field, none is yet in force and there is thus no experience of their operation in practice.

\section{Concluding remarks}

Complcting the single market in insurance is a long and hard task, extending far beyond 31 December 1992. It is likely that the Third Directives, whenevcr they nominally enter into force, will contain secondary deadlines, similar to those already noted in the Second Life Directive. If so, they will probably not be completely applied everywhere until the end of the century. Moreover, they may not be enough. 
Sir Leon Brittan has said: "Our goal ... will only be fully realized ... when any of these financial institutions can market the full range of its financial services and financial products across frontiers" - he might have added: or through branches - "to any customer in any Member State as easily as it can at home". Although the Commission's explanatory memorandum on the proposal for the Third Life Directive asserts that it "will result in the full completion of the internal market", we have noted why it may fall short of Sir Leon's goal.

In any case, the single market will by no means be a uniform market, especially in the forms of insurance where the main customer is the man in the street. For example, claims costs, and therefore premium rates, will differ widely in motor insurance from one Mcmber State to another for a host of reasons; and life insurance as a means for individuals to save for retirement will be differently perceived according to the levels of social security and private employment-based pensions in different countries.

In spite of these rather negative considerations, it is apparent that an irreversible movement is taking place.

Insurance companies already started making their moves as soon as they realized that the Community seriously intended to give effect to the 1992 programme. The major insurance groups have sought to achieve an EC-wide presence, often through acquisitions and mergers. Even in non-life insurance, insurers are not relying much on expectations of cross-frontier sales. In life insurance, they do not appear to be doing so at all. What the companies do expect is that the creation of the internal market in insurance will significantly change both the regulatory framework and the expectations of the buying public, thereby creating new opportunities and increased competition. They are preparing themselves for it and thereby helping to ensure that it will come about.

\section{ANNEX 1 \\ NON-INSURANCE DIRECTIVES MENTIONED IN TEXT}

\section{UCITS Directive}

Council Directive $85 / 610 /$ EEC of 20 December 1985 on the coordination of laws, regulations and administrative provisions relating to collective investment in transferable securities (UCITS). OJ L 375, 31.12.1985, p. 3.

\section{Second Banking Directive}

Council Directive $89 / 646 /$ EEC of 15 December 1989 on the coordination of laws, regulations and administrative provisions rclating to the taking up and pursuit of the business of credit institutions and amending Directive 77/780/EEC. OJ L 386, 30.12.1989, p. 1.

\section{Fourth Directive on Company Accounts}

Fourth Council Directive 78/660/EEC of 25 July 1978 based on Article 54 (3) (g) of the Treaty on the annual accounts of certain types of companies. OJ L 222, 14.8.1978, p. 11.

\section{Seventh Directive on Consolidated Accounts}

Seventh Council Directive 83/349/EEC of 13 June 1983 based on Article 54 (3) (g) of the Treaty on consolidated accounts. OJ L 193, 18.7.1983, p. 1. 


\section{INSURANCE DIRECTIVES}

\section{Directives already adopted}

The Directives listed here are already in force except where otherwise indicated.

\section{Reinsurance and retrocession}

\section{Reinsurance Directive}

Council Directive 64/225/EEC of 25 February 1964 on the abolition of restrictions on freedom of establishment and freedom to provide services in respect of reinsurance and retrocession. OJ L 56, 4.4.1964, p. 878.

Provides freedom of establishment (branching) and cross-frontier services for reinsurance and retrocession.

\section{Direct Non-Life Insurance}

\section{First Non-Life Directive}

First Council Directive 73/239/EEC of 24 July 1973 on the coordination of laws, regulations and administrative provisions relating to the taking up and pursuit of the business of direct insurance other than life assurance. OJ L 228, 16.8.1973, p. 3.

The basic Directive on which the others have built. Lays down the admissible legal forms for insurance undertakings. Restricts their activities to insurance and immediately derived activities. All classes of insurance must be supervised. Head office State has general control and supervises solvency margin. Each State where insurer established supervises technical reserves etc. Right to open branches in other Member States guaranteed if certain conditions met. Prescribed steps if things go wrong. Cooperation between national supervisory authorities.

\section{Non-Life Establishment Directive}

Council Directive 73/240/EEC of July 1973 abolishing restrictions on freedom of establishment in the business of direct insurance other than life assurance. OJ L 228 , 16.8.1973, p. 20.

The companion Directive to the First Non-Life Directive. It formally abolished discriminations based on nationality; but a later Court judgment declared that most of what this Directive does flows automatically from the Treaty of Rome without any need for a Directive.

\section{ECU Directive}

Council Directive 76/580/EEC of 29 June 1976 amending Directive 73/239/EEC on the coordination of laws, regulations and administrative provisions relating to the taking up and pursuit of the business of direct insurance other than life assurance. OJ L 189, 13.7.1976, p. 13.

A technical adjustment to the First Non-Life Directive, concerning amounts expressed in what are now known as ECU (European currency units). 


\section{Tourist Assistance Directive}

Council Directive 84/641/EEC of 10 December 1984 amending, particularly as regards tourist assistance, the First Directive (73/239/EEC) on the coordination of laws, regulations and administrative provisions relating to the taking up and pursuit of the business of direct insurance other than life assurance. OJ L 339, 27.12.1984, p. 21.

Amends the First Non-Life Directive and makes clear that it applies to undertakings providing practical assistance, such as repatriation, to travellers and holidaymakers if a premium-like initial payment guarantees intervention on the occurrence of a chance event. Optional application to other "assistance" circumstances. Automobile clubs can escape application of the Directive.

\section{Credit Insurance Directive}

Council Directive 87/343/EEC of June 1987 amending, as regards credit insurance and suretyship insurance, the First Directive $73 / 239$ /EEC on the coordination of laws, regulations and administrative provisions relating to the taking up and pursuit of the business of direct insurance other than life assurance. OJ L 185, 4.7.1987, p. 72.

Amends the First Non-Life Directive. Provides that Germany must abandon her specialization requirement for credit and suretyship insurance. Insurers carrying on credit insurance must establish equalization reserves using one of four methods, stated to be equivalent. State-backed export credit insurance remains outside the scope of the Insurance Directives.

\section{Legal Expenses Insurance Directive}

Council Directive 87/344/EEC of 22 June 1987 on the coordination of laws, regulations and administrative provisions relating to legal expenses insurance. OJ L 185, 4.7.1987, p. 77.

In substance, amends and expands the First Non-Life Directive. Provides that Germany must abandon her specialization requirement for legal expenses insurance. Seeks to remove conflicts of interest where the same insurer provides legal expenses and other cover, especially civil liability cover.

\section{Agreement with Switzerland}

(1) Council Decision $91 / 370 / E E C$ of 20 June 1991 on the conclusion of the agreement between the European Economic Community and the Swiss Confederation concerning direct insurance other than life assurance.

(2) Council Directive $91 / 371 / E E C$ of 20 June 1991 on the application of the agreement between the European Economic Community and the Swiss Confederation concerning direct insurance other than life assurance.

(3) Council Regulation (EEC) no. 2155/91 of 20 June 1991 establishing special provisions for the application of Articles 37, 39 and 40 of the agreement between the European Economic Community and the Swiss Confederation concerning direct insurance other than life assurance. (1), (2) and (3) all appear in OJ L 205, 27.7.1991.

The Agreement applies only to non-life direct insurance. It enables Swiss insurers to set up and maintain branches in EC Member States, and EC insurers to set up and maintain branches in Switzerland, under the conditions laid down in the First NonLife Directive (see above). Swiss insurers will no longer need to maintain a separate 
solvency margin, and assets representing it, in EC Member States where they have branches. The Agreement does not enable Swiss insurers to sell insurance directly across frontiers from the head office in Switzerland into an EC Member State, nor from a branch in one Member State into another Member State; nor does it enable EC insurers to sell directly across frontiers into Switzerland.

Enters into force on a date to be determined (probably 1 January 1994).

\section{Coinsurance Directive}

Council Directive 78/473/EEC of 30 May 1978 on the coordination of laws, regulations and administrative provisions relating to Community coinsurance. OJ L 151, 7.6.1978, p. 2.

The first Directive concerned with freedom of cross-frontier services. Restricted to coinsurance where at least two of the coinsurers cover the risk from establishments in different Member States. The risk must be of a nature or size such that coinsurance is a normal procedure. Lays down rules for collaboration between supervisory authorities, based on home country control. The Coinsurance Directive is now largely integrated with the Second Non-Life Directive (see below).

\section{Second Non-Life Directive}

Council Directive 88/357/EEC of 22 June 1988 on the coordination of laws, regulations and administrative provisions relating to direct insurance other than life assurance and laying down provisions to facilitate the effective exercise of freedom to provide services and amending Directive 73/239/EEC. OJ L 172, 4.7.1988, p. 1.

Amends the First Non-Life Directive to provide a firmer basis for the exercise of cross-frontier services, and lays down two separate regimes for such services. For "large risks", home country control applies (supervision in State where insurer is established), whereas for "mass risks" (all cases other than large risks), the State where the risk is situated may require the insurer to be authorized and to obey that State's rules on technical reserving, assets and policy conditions.

Entered into force on 30 June 1990 but various provisions have delayed application to a number of Member States.

\section{Direct Life Insurance}

\section{First Life Directive}

Council Directive 79/267/EEC of 5 March 1979 on the coordination of laws, regulations and administrative provisions relating to the taking up and pursuit of the business of direct life assurance. OJ L 63, 13.5.1979, p. 1.

The companion Directive to the First Non-Life Directive. Rules for the solvency margin reflect the mixed risk-bearing and investment nature of much life business. No new composite insurers (carrying on both life and non-life) may be formed.

\section{Second Life Directive}

Council Directive 90/619/EEC of 8 November 1990 on the coordination of laws, regulations and administrative provisions relating to direct life assurance, laying down provisions to facilitate the effective exercise of freedom to provide services and amending Directive 79/267/EEC. OJ L 330, 29.11.1990, p. 50. 
A distinction is drawn between active cross-frontier marketing (active provision of services) and approaches from own-initiative buyers (passive provision of services). In the active case, the policyholder's State may require authorization, and control the technical provisions and assets under its own rulcs. In the passive casc, there is no authorization in the policyholder's State and the technical provisions and assets arc supervised in the home Statc.

Enters in force 20 May 1993, but some provisions have later application dates (own initiative in cmployment-related group insurance 31 December 1994, own initiative through brokers 20 May 1996, and spccial treatment for Grcece, Spain and Portugal during a transitional period).

\section{Motor Insurance}

\section{First Motor Insurance Directive}

Council Directive 72/166/EEC of 24 April 1972 on the approximation of the laws of Mcmbcr States relating to insurance against civil liability in respect of the use of motor vehicles, and to the enforcement of the obligation to insure against such liability. OJ $L$ 103, 2.5.1972, p. 1 .

\section{First Motor Insurance Directive (Amendment)}

Council Directive 72/430/EEC of 19 December 1972 amending Council Directive 72/166/ EEC of 24 April 1972. OJ L 291, 28.12.1972, p. 162.

All compulsory motor insurance issued in any Member State must provide cover for liability arising out of the use of the vehicle in all the Member States, up to the legal minimum laid down (separately) by each State. When taken together with the Supplementary Agreement between the Motor Insurers' Bureaux of the Member States (and some non-Member States) and a series of Commission Decisions, this made possible the suppression of green card checks at frontiers. Some dozen Decisions and Recommendations have been adopted in this field.

\section{Second Motor Insurance Directive}

Second Council Directive 84/5/EEC of 30 December 1983 on the approximation of laws of the Member States relating to insurance against civil liability in respect of the use of motor vehicles. OJ L 8, 11.1.1984, p. 17.

Fixes minimum levcls of compulsory liability cover and sceks to align the scope of such cover throughout the Community.

Certain Member States havc application dates running to 31 December 1995 for the application of particular provisions in this Directive.

\section{Third Motor Insurance Directive}

Third Council Directive 90/232/EEC of 14 May 1990 on the approximation of the laws of the Member States relating to insurance against civil liability in respect of the use of motor vehicles. OJ L 129, 19.5.1990, p. 33.

Removes certain anomalies in compulsory third party cover and ensures better protection for victims. In particular, compulsory third party cover issued in any Member State will apply, in the case of each visited State, up to the higher of: 
- the cover required by law in the visited State and

- the cover recuired by law in the home State of the vehicle.

Cover must extend to liability for personal injuries to all passengers, other than the driver, arising out of the use of the vehicle.

Enters into force on 31 December 1992 (but certain provisions do not apply until 31 December 1995 to Greece, Spain, Ireland and Portugal and one provision does not apply to Ireland until 31 Decembcr 1998).

\section{Fourth Motor Insurance Directive}

Fourth Council Directive 90/618/EEC of 8 November 1990 amending, particularly as regards motor vchicle liability insurance, Dircctivc 73/239/EEC and Directivc 88/357/ EEC which concern the coordination of laws, regulations and administrative provisions relating to direct insurance other than life assurance. OJ L 330, 29.11.1990, p. 44.

Integrates all motor insurance (liability and other) into the regime for frecdom of services set up by the Second Non-Life Directive, with distinction between large risks and mass risks (but full large-risk trcatment may be delayed). An insurer providing cross-frontier civil liability cover must join the motor insurers' bureau and guarantee fund of the State wherc the vehicle is registered, and appoint a representative there to assist in dealing with claims.

Enters into force on 20 November 1992 but with delayed cffect for some provisions concerning large risks.

\section{Insurance Accounts Directive}

Council Directive 91/674/EEC of 19 December 1991 on the annual accounts and consolidated accounts of insurance undertakings. OJ L 374, 31.12.1991, p. 7.

The Fourth and Seventh Directives on company accounts will apply to insurance undcrtakings, except to the (considerable) cxtent that this Directive provides otherwise. This Dircctive applies to specialist reinsurers as well as direct insurers, whatever their legal form. It is intended to enable information on the financial situation of insurers to be available in standard comprehensive form, but contains a number of options. Its rules on technical reserving are detailed for non-life insurance, but less so for life insurance. Investments must be disclosed at both current value and historical cost (whichever value is not shown in the balance sheet must be disclosed in the notes). The accounts of insurance undertakings are integrated into the general systcm of consolidated accounts.

Entry into force: the Directive must bc incorporated in national legislation by 1 January 1994. It must be applicd to annual accounts and consolidated accounts for financial ycars beginning on 1 January 1995 or later in that ycar. Disclosurc of the current valuc of investments may be deferred until 1 January 1997 ( 1 January 1999 for land and buildings).

\section{Intermediaries}

\section{Insurance Intermediaries Directive}

Council Directive 77/92/EEC of 13 December 1976 on measures to facilitate the effective exercise of freedom of establishment and frcedom to provide services in respect of the activities of insurance agents and brokers (ex ISIC group 630) and, in particular, transitional measures in respect of those activitics. OJ L 26, 31.1.1977, p. 14. 
Some Member States have qualifications for access to the activities of brokers and agents. Others do not. Where qualifications exist, they vary from one State to another. This Directive provides that certified experience at stated levels shall be regarded as equivalent to formal qualifications, so that brokers and agents having such experience may work throughout the Community.

\section{Insurance Intermediaries Recommendation}

Commission Recommendation 92/48/EEC of 18 December 1991 on insurance intermediaries. OJ L 19, 28.1.1992, p. 32.

This recommendation, lacking binding force, urges Member States to ensure that insurance intermediaries (brokers and agents) are subject to professional requirements and registration, that brokers are genuinely independent, and that all intermediaries have adequate professional knowledge and have professional indemnity insurance (or other guarantees).

\section{Administration}

Insurance Committee Directive

Council Directive 91/675/EEC of December 1991 setting up an Insurance Committee. OJ L 374, 31.12.1991, p. 32.

The Insurance Committee, composed of representatives of the Member States and chaired by a representative of the Commission, provides a framework within which the Commission may exercise implementation powers conferred on it by the Council, reviews the application of Community provisions in the insurance sector and advises on possible new measures.

\section{Directives proposed but not yet adopted}

Short Title
Insurance
Contracts
Compulsory
winding up
of insurance
undertakings
Third
Non-Life
Directive
Third Life
Directive

Short Title

Purpose

Partial harmonization of non-life contract law

Adequate and comparable protection for policyholders throughout the Community

Single authorization; home country control in all cases.

Single authorization; home country control in all cases.

\author{
Timing \\ Proposed 1979. \\ Not being actively \\ pursued at present. \\ Proposed end 1986 \\ Revised 1989. No \\ prospect of early \\ adoption. \\ Proposal 18. 7. 90. \\ Adoption likely \\ Summer 1992.
}

Proposal 20. 2. 91. 


\section{ANNEX II}

\section{Qualified majority voting}

Where the Council is required to act by a qualified majority, the votes of its members shall be weighted as follows:

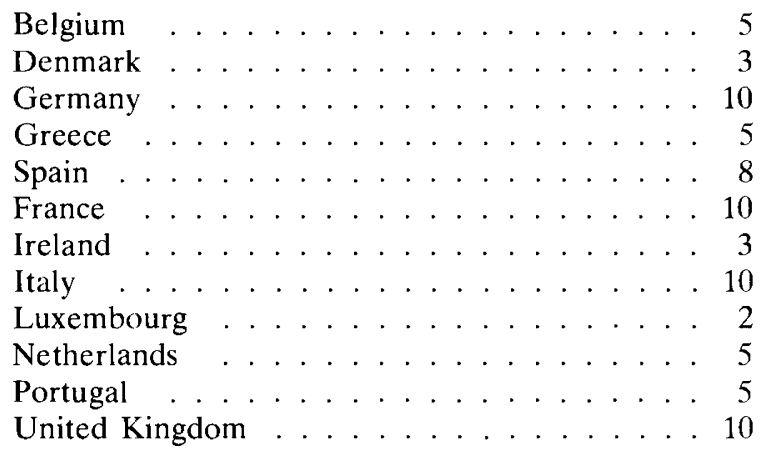

For their adoption, acts of the Council shall require at least:

- fifty-four votes in favour where this Treaty requires them to be adopted on a proposal from the Commission

- fifty-four votes in favour, cast by at least eight members, in other cases. (EEC Treaty [Treaty of Rome], Article 148(2))

It will be seen that the number of votes is related to the population of each country, but weighted in favour of the smaller ones.

Qualified majority voting does not apply to fiscal provisions, to those relating to the free movement of persons nor to those relating to the rights and interests of employed persons. For these, unanimity is required (but "abstentions by members present in person or represented shall not prevent the adoption by the Council of acts which require unanimity" - EEC Treaty, Article 148(3)). 